Ankara Eez. Fak. Mec.

5. 113. (1975)
J. Fac, Pharm Ankara

5. 113. (1975)

\title{
Delphinium formosum Boiss et Huet Bitkisinin Alkaloitleri Yönünden Kimyasal Araștırmalar
}

Recherches Chimiques Sur Les Alcaloides de D. formosum Boiss et Huet.

Mekin TANKER* Seglkin ÖZDEN**

Delphinium formosum Boiss et Huet (Ranunculaceae) Türkiye'nin kuzeydoğu ve doğusunda yetişmekte olan bir bitkidir. Bu bitki bölge halkı tarafından ahırların tabanına serilerek büyük ve küçükbaș hayvanların dıș parazitlere karșı korunması gayesiyle kullanılmaktadır. Ayrıca bitki kök ve yaprakları toz edilip lapa hazırlanarak hayvanlara sürülerek de kullanılır. Bu lapadan insan bitlerine karşı da faydalanılmaktadır.

D. formosum bitkisi üzerinde şimdiye kadar çalıșılmıș değildir. Halk hekimliğince insan ve hayvan sağlığında faydalanılmakta olan bu bitkinin, yapılan ön deneylere göre diğer Delphinium türlerinde olduğu gibi bazı alkaloitler ihtiva ettiği anlaşılmıștır. Çalışmalarımızı bu alkaloitler üzerinde yoğunlaştırdık. Delphinium türlerinden elde edilen alkaloitler pentasiklik veya tetrasiklik diterpen alkaloitleridir. Bilindiği gibi bu tip alkaloitler ya 19 karbonlu alkaminler veya 20 karbonlu alkaminler yahut ta bunların esterleridir. Diterpen alkaloitlerinden bu güne kadar bilinenlerde 4 tip iskelete raslanmıștır. Bunlar veatçin, atizin, likoktonin ve heteratizin'dir.

Delphinium alkaloitleri daha çok likoktonin iskeleti taşımaktadirlar, Ilk defa 1865 yilında $A$. Lycoctonum, L, den izole edilen likoktonin, Aconitum ve Delphinium türlerinde bulunan ester alkaloitlerinin belli başl alkaminidir ve bu iki cinsten elde edilen al-

\footnotetext{
Redaksiyona verildiği tarih: 9. Mayıs. 1975

- Farmakognozi Kürsüsü, Eczacılık Fakültesi, Ankara Öniversitesi

** Farmasötik Kimya Kürsüsü, Eczacılık Fakültesí, Ankara Üniversitesi,
} 
kaloitlerin kimyasal yapıları arasındaki yakınlı̆̆ı göstermesi bakımindan önemlidir. $\mathrm{C}_{19}$ iskeletine sahip Delphinium alkaloitleri likoktonin yapısındaki alkaloitler haricinde, akonitin yapısında alkaloitler de ihtiva ederler. Bu guruptan olan delfinin, alkonitin ile büyük benzerliğe sahiptir.

$\mathrm{C}_{20}$ iskeletine sahip Delphinium alkaloitleri daha çok atizin iskeleti ile modifiye atizan iskeletine sahiptirler.

Delphinium 'ların ihtiva ettikleri alkaloitler çeșitli kimyasal çalıșmalara konu olmuștur. Kimyasal yapıları bakımından Aconitum' lara çok yakın oldukları gibi, fizyolojik tesirleri de bir çok bakımlardan aynidir ve zehirlidirler. Bu nedenle Delphinium 'lardan dolayı zehirlenme vakaları oldukça fazladır. Delphinium'ların bu toksik tesirlerine karșılık, veteriner ve tıpta kullanılıș sahası geniștir. D. ajacis L., den elde edilen preparatlar (N.F. VI, U.S.P. IX, B.P., B.P.C) parazitisit ve ensektisit olarak kullanılmaktadır. Hatta bir zamanlar antispazmodik ve antinevraljik olarak ta kullanılmıştir. (8)

Yukarıda da belirtildiği gibi toksik bir bitki olduğu halde, faydalı yönlerinden dolayı ve halen halk sağlığında kullanılması, ayrıca kimyası ve toksisitesi üzerinde hiç bir çalıșma yapılmamış olması ve belirli bir bölgede fazla miktarda yetișmesi nedeniyle, Delphinium türlerinden biri olan $D$. formosum Boiss et Huet üzerinde çalışmayı uygun bulduk.

\section{MATERYAL Ve METOT}

Delphinium formosum Boiss et Huet., Kuzey Anadolu'nun belirli bir yöresinde $1500-2700$ metre yükseklikte, nispeten nemli topraklarda, çayırlarda ve dere kenarlarında tarlalar halinde bulunur.

Temmuz ve ağustos aylarında çiçek açan $D$. formosum Boiss et Huet $60-180 \mathrm{~cm}$. boyunda çok senelik bir bitkidir. Gövde yatık tüylerle kaphıdır. Yapraklar alternan dizilişi, saph, palmat lobludur. Çiçek durumu salkım, $15-20 \mathrm{~cm}$. kadar uzunlukta $3-4 \mathrm{~cm}$. kadar, mavimsi mor renkli, zigomorf ve mahmuzludur. Meyva hav fif tüylü, 3 folikülden ibarettir. 
Toprak altı kısmı, muntazam olmayan bir rizom şeklindedir. Her taraftan saçak şeklinde çıkabilen 1-3 mm. çapında köklere sahiptir.

Çalışma materyalimiz olan Delphinium formosum Boiss et Huet 1968 yılının Ağustos ayı içerisinde Trabzon'un Sürmene Santa yaylasından toplandı. Bitkinin çiçek, yaprak, sap ve toprak alts kısimları birbirinden ayırıldı ve toprak vs. den temizlendikten sonra fazla suyunu çekene kadar toplanildı̆ı yerde, gölgede ve havadar bir ortamda 3 gün bekletildikten sonra laboratuvara getirildi. Laboratuvar isisinda tamamen kurutuldu.

Bitkinin çiçek, yaprak, sap ve toprak altı kısımlarından hangisinin alkaloit yönünden daha zengin olduğunun tesbiti için incr tabaka kromatografisi yapıldı. Bunun için bitkinin bu kısımlarından ayrı ayr eșit gramlardan hareketle tüm alkaloit ekstreleri hazırlandi. Ince tabakaya birbirine eșit miktarlarda tatbik edildi. Elde edilen lekelerin Dragendorff ile verdikleri renk șiddetine ve lekelerin sayısına bakıldığı zaman, alkaloit yönünden, bitkinin en zengin kısmının toprak altı kısımlan olduğu anlaşıldı. Büttïn çalıșmalarda değirmende ögüitülerek ince toz haline getirilmiș bu toprak altı kısımları kullanıldı.

Delphinium alkaloitleri genellikle ester alkaloitleri olup sicakta yapılan alkaloit tüketim metotları tatbik edilememektedir. Normal hararette asitlendirilmiș metanol veya doğrudan doğruya sulu etanol veya metanol ile yapilan tüketimlerde ise elde edilen hülâsanın su ihtivà etmesi, alçak derecede yoğunlaștırmayı güçleștirmekte ve organik solvanlarla yapılan tüketimlere göre ekstre daha fazla yan maddeler ihtiva etmektedir.

Bu sebeple organik solvanlarla yapilan tüketimler daha uygundur. Yalnız drogu önceden bir alkali ile ıslatarak organik solvanla tüketmek, așırı solvan sarfını ve oda isısında tüketmek suretiyle de alkaloitlerin hidroliz olma ihtimalini azaltir.

Bu noktalar göz önüne almarak Delphinium formosum toprakaltı kısımları alkaloitlerinin tüketilmesi için toz haline getirilmiș materyal amonyak ile sslatıld 1 ve benzolle perkole edildi. Perkolat alçak basınçta ve düișük ısıda konsantre edidi. Konsantre hülâsadan alkaloitler asitli su ile tüketilerek alındı. Asitli çözelti pet- 
rol eteri ile birkaç kere yıkandıktan sonra amonyak çözeltisi ile kalevilendirildi. Bu çözeltiden alkaloitler kloroform ile tüketildi. Kloroformlu tüm alkaloit ekstresi vakumda düșïk ısıda kuruluğa kadar buharlaştirldı. Böylece nispeten temiz tiim alkaloit ekstresi elde edildi. Çözeltileri halinde alkaloitlerin hidroliz olduğu tespit edildiği için, kullanılacağı zaman, çözeltisi hazırlanmak üzere desikatörde muhafaza edildi.

$\mathrm{Bu}$ şekilde hazırlanan tüm alkolit ekstresi ince tabakaya tatbik edildiği zaman $\mathrm{R}_{\mathrm{f}}$ değerleri farkl 6 alkaloit lekesi verdi. $\mathrm{Bu}$ alkaloitlerin izolasyonu için sütun ve preparatif ince tabaka kromatografisinden tam bir netice alınamadı. Zira solüsyonları halinde dahi kolayca hidroliz olabilen Delphinium alkaloitleri, sütun ve preparatif ince tabaka kromotografisinin yapilabilmesi için lüzumlu olan zaman zarfinda ve ayrica adsorbanların tesiriyle de parçalanabilmektedir. Bu sebeple, bu 6 alkaloidin kristalizasyon çalışmaları ile izole edilmesine çalışıldı. Benzollü tüm alkaloit ekstresi su ile doyurulup birkaç gün soğukta birakıldığında, 6 alkaloitten miktarca en fazla olan $\mathrm{A}_{3}$ alkaloidi, kristaller halinde ayrild. Geriye kalan benzollü ekstre birkaç kere su ile muamele edildi. Ayrilan sulu kisımlarm kloroform ile tüketilmesiyle ikinci bir alkaloit daha ekstreden kloroforma çekilmiș oldu. Kloroformlu çözelti konsantre edildikten sonra petrol eteri ile doyurulup, soğukta birakıldığında da $\mathrm{A}_{2}$ olarak isimlendirilen bir alkaloit daha kriställer halinde izole edilmiș oldu.

Saf olarak elde edilen bu iki alkaloidin teșhisi için ergime noktası, polarize ışı̆̆ı çevirme derecelerine bakıldıktan sonra her iki alkaloidin de asit ve alkali hidrolizleri yapılarak hidroliz ürünleri ilicelendi. Bu șekilde $A_{\perp}$ alkaloidinin ester grubu tașımadığ ${ }_{1}, A_{3}$ alkaloidinin ise bir ester alkaloidi olduğu anlașilarak, ester grubunu teșkil eden asitler ve alkamini saf halde elde edip ergime noktaları ve polarize 1 șığı çevirme dereceleri tayin edildi.

Delphinium türlerinden izole edilen alkaloitler içinde yegane temin edebildigimiz delfinin (Fluka) ve kimyasal yapılarındaki büyü benzerliklerinden dolayı mukayesesì lüzumlu görülen akonitin (Merck) ve hidroliz ürünleri ince tabaka kromatografisi yardımı ile mukayese edildi. 
$A_{1}$ ve $A_{3}$ alkaloidi ve $A_{3}$ alkaloidi alkamininin $U V, I R, N M R$ ve mass spektrumları alınd.

Ayrica bu alakloitlerden $\mathrm{A}_{3}$ alkaloidinin hidroklorik asit, perklorik asit tuzu, $\mathrm{A}_{1}$ alkaloidinin hidroklorik asit, hidrobromik asit, hidroiyodik asit, perklorik asit pikrik asit tuzları elde edilerek ergime noktaları tayin edildi.

Asetile türevlerinin hazırlanmasına çalıșıldıysa da sadece $A_{t}$ alkaloidinin asetilasyonu bașarilabildi.

Alkaloit miktar tayini : $\mathrm{Ph}$. Int. in Aconitum alkaloitleri için vermiș olduğu metot ile ve gravimetrik yolla tayin edildi.

\section{B U L G U L A R}

D. formosum Boiss et Huet'in toprak altı kisımlarından elde edilen kuru tüm alkaloit ekstresi, kullanılacağı zaman alınmak üzere desikatörde muafaza edildi. Sarı renkli, amorf görünüșlü olan bu kuru tüm alkaloit ekstresi, kloroform, benzen, metanol ve absolu etanolde tamamen, eterde artık bırakarak çözünür. Bütün alkaloit testlerine müspet cevap verir.

$\mathrm{Bu}$ tüm alkaloit ekstresinin, tek bir madde veyahut ta karışım olup olmadığının tespiti için, ince tabaka kromotografisi ile verdiği neticeler incelendi. Değişik solvan sistemleri ve farklı adsorbanlarla ve de revelatör olarak Dragendorff kullanarak yapılan incelemeler neticesinde elde edilen leke sayısı ve $R_{f}$ değerleri (Tablo: 1 ) de gösterilmiștir.

Bu kromotografik analizden elde edilen neticeye göre: $D$. formosum toprak altı kısımlarından elde edilen tüm alkaloit ekstresi 6 alkaloit karıșımından ibarettir. Bu lekeler așağıdan yukariya $A_{1}: A_{2}: A_{3}: A_{4}: A_{5}: A_{6}$, olarak rümuzlandırildı. (Kromatogram : 1) Böylece tüm alkaloit ekstresinde alkaloitlerin ayrılması için uygun adsorbanin Kieselgel-G, solvanin da benzen: metanol eter (70:20.20) karışımı olduğu görüldü. Revelatör kullanmadan önce alkaloitlerin UV ıșığı altında gösterdikleri florasans incelendi. Buna göre $A_{1}$ lekesi hariç diğerlerinin mor renkte floresans verdiği tespit edildi. 
Tablo : I

\begin{tabular}{|c|c|c|c|}
\hline $\begin{array}{l}\text { Solvan } \\
\text { Sistemleri }\end{array}$ & Adsorban & Leke Sayısı & $\mathbf{R}_{\mathrm{f}}$ Değerleri \\
\hline $\begin{array}{l}\text { Kloroform : Metanol : } \\
\text { Su }(80: 20: 2)\end{array}$ & Kieselgel-G & 5 & 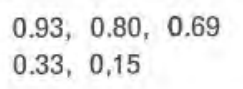 \\
\hline $\begin{array}{l}\text { Benzen : Metanol : } \\
\text { Eter }(70: 20: 20)\end{array}$ & " & 6 & $\begin{array}{lll}0.69, & 0.60, & 0.50 \\
0.44, & 0.33, & 0.10\end{array}$ \\
\hline $\begin{array}{l}\text { Kloroform : Metanol } \\
(95: 5)\end{array}$ & $"$ & 3 & $0.94,0.86,0.17$ \\
\hline $\begin{array}{l}\text { Kloroform : Metanol } \\
(98: 2)\end{array}$ & $\begin{array}{l}\text { Aluminyum } \\
\text { Oksit }\end{array}$ & 4 & $\begin{array}{l}0.93,0.77,0.66 \\
0.10\end{array}$ \\
\hline $\begin{array}{l}\text { Siklohekzan: Kloro- } \\
\text { form : Metanol } \\
(100: 60: 10]\end{array}$ & $n$ & 4 & $\begin{array}{lll}0.90, & 0.62, & 0.29 \\
0.14 & \end{array}$ \\
\hline
\end{tabular}

Ayrica delfinin, akonitin, ve $D$. formosum Boiss et Huet, den izole edilen $A_{1}, A_{3}$ ve ayrıca dördünün hidroliz ürünleri ince tabaka kromatografisinde birbirleriyle mukayese edildi. (Kromatogram 2). $\mathrm{Bu}$ kromatografik analizden $D$. formosum Boiss et Huet alkaloitlerinin, denenen șahitlerden hiçbiri ile tam bir uygunluk göstermediği anlașılmıștır.

D. formosum toprak altı kısımlarında tüm alkolit miktar tayini :

a) Titrimetrik yolla :

$\mathrm{Ph}$. Int. in Aconitum alkaloitleri için vermiș olduğu tüm alkaloit miktar tayini metoduna göre yapıldı. $\mathrm{Bu}$ șekilde yapılan tüm alkaloit tayinine göre netice delfinin üzerinden hesaplanırsa, D. formosum Boiss Et Huet toprak altı kısımları alkaloitleri için bulunan miktar \% 2.08 dir.

b) Gravimetrik yolla :

Literatürde tespit edebildiğimiz Delphinium türlerine tatbik edilen miktar tayini metotlarının hepsi gravimetrik yolladır. $(4,15)$. 
Bu şekilde $D$. formosum Boiss et Huet toprak altı kısımları alkaloitleri için bulunan miktar \% $2.7 \mathrm{dir}$.

\section{Baz Halindeki Tüm Alkaloit Ekstresi Üzerinde Yapılan Kristalizasyon Çalıșmalarıyla Alkaloitlerin İzolasyonu}

Sütun ve preparatif ince tabaka kromatografisi ile alkaloitler, birbirinden ayrılmaya çalıșıldıysa da arzu edilen bir neticeye varılmadığı için tüm alkaloit ekstresinden hareketle, serbest baz halinde alkaloitler kristallendirilmeye çalışıldı. $B u$ şekilde $A_{1}$ ve $A_{3}$ alkaloidi, tüm ekstrenin ihtiva ettiği 6 alkaloitten kristallenerek ayrildilar.

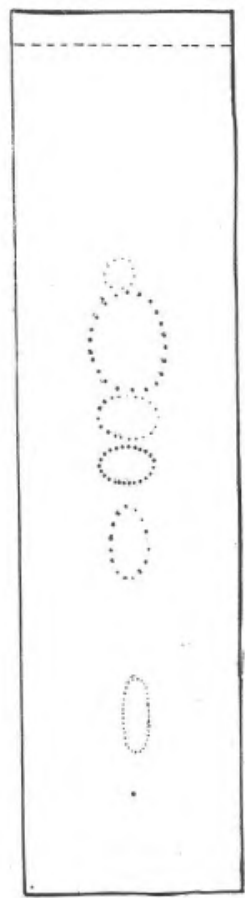

Krom. 1 Benzen : metanol : eter (70:20:20)

Developman : 45 Dakika

Oda Isısı : $25^{\circ} \mathrm{C}$ 


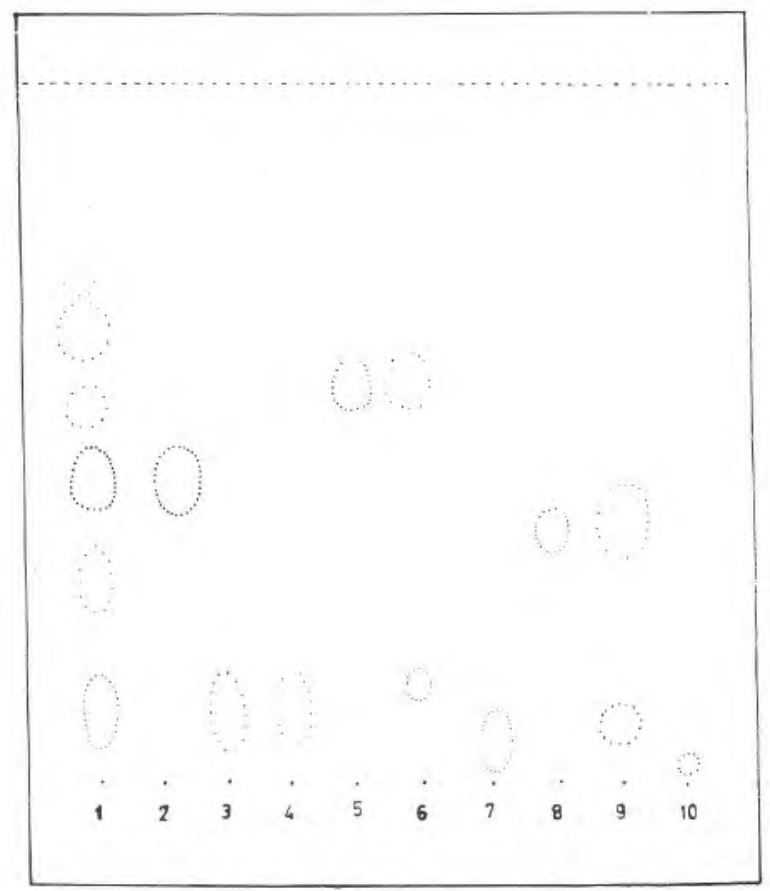

Krom. 2. Benzen : Metanol : eter (70:20:20)

Developman : 55 Dakika

Oda ISISI : $25^{\circ} \mathrm{C}$

1) Tüm alkaloit ekstresi. 2) $A_{3}$ Alkaloidi. 3) $A_{3}$ Alkaloidi alkali hidroliz ürünü. 4) $A_{l}$ Alkaloidi. 5) Akonitin. 6) Benzoil akonin. 7) Akonin. 8) Delfinin. 9) Benzoildelfonin. 10) Delfonin.

$\mathbf{A}_{1}$ maddesi: Kloroform + petroleterinden kristallendirilen bu madde renksiz iğnecikler halinde kristaller olup Dragendorff ve diğer alkaloit reaktifleri ile istenen renkleri vermektedir. Maddenin baz halinde ergime noktası $143^{\circ} \mathrm{C}$ dir. Optik çevirme derecesi ise $(\alpha)^{20} \mathrm{D}=53 \mp 1$ dir.

Ince tabaka kromatografisinde $\mathrm{R}_{\mathrm{f}}$ değeri 0,10 olarak bulunmuştur. Alkali hidroliz sonunda elde edilen maddenin E.N. sı ve optik çevirme derecesi yine $A_{1}$ alkaloidi ile aynıdır. Böylece $A_{1}$ alkaloidinin ester grubu taşımadığı anlaşılmıştır. Yapılan elementer analiz neticesinde C: $\% 61,82$ H: $\% 8,79 \quad$ N. \% 26,37 $\quad$ O: $\% 3,02$ olarak bulunmuştur. 
Maddenin Mass spektrumunda molekül ağırlığının 467 mol. g. oldugúu tespit edilmiştir.

Aynca alkaloidin elde edilen tuzlarmm ergime noktalan : Hidroklorik asit tuzu $152-154^{\circ} \mathrm{C}$, Hidrobromik asit tuzu $185-187^{\circ} \mathrm{C}$, Hidroiyodik asit tuzu $175^{\circ} \mathrm{C}$, Perklorik asit tuzu $212-215^{\circ} \mathrm{C}$ ve Pikrik asit tuzu $161^{\circ} \mathrm{C}$ bulunmuștur.

Bütün bu özelliklerin, literatürde $(1,5,6,9,10,11,12,22,23,24)$ likoktonin'e ait özellikler olduğu görülmektedir. Standart likoktonin maddesi temin edemediğimiz için klâsik kimyasal yollarla maddenin yapı tayini ve mukayesesi vapılamadığından aletsel analiz metotlarından istifade edilmiștir.

UV spektrumu : Maddenin 200-400 $\mathrm{m} \mu$ dalga boyları arasinda incelenen absorbsiyonunda molekülün tamamen ıșığı geçirici olduğu kromofor grupların bulunmadığı görüldüi. (Spektrum: 1) $A_{4}$ maddesinin UV spektrumu $D$. barbeyi (1) H.'den izole edilen 1ikotonin'in UV spektrumuyla mukayese edildiğinde her iki spektrumun da birbirine uyduğu görüldü; (Spektrum: 2)

IR Spektrumu: Maddenin IR Spektrumunun incelenmesinde (spektrum: 3) 3571-3333 $\mathrm{cm}^{-1}$ de elde edilen kuvvetli bantlar serbest hidroksil gruplarını varlığını, 3030-2778 $\mathrm{cm}^{-1}$ deki bantlar metil veya metilen gruplarm belirtmektedir. $1150-1225 \mathrm{~cm}^{-1}$ deki kuvvetli pikler tersiyer amin grubunun varlığını gösterir. Doymuș sekonder alkol fonksiyonun varlığı ise $1100 \mathrm{~cm}^{-1}$ de elde edilen bantla ortaya çıkmaktadır. $A_{1}$ maddesinin bu spektrumu, likoktoninin (7) IR spektrumu ile karşılaştırıldığında her iki spektrumun da aynı bantları verdiği görülmektedir. (2, 3, 16). (Spektrum: 4.5).

NMR Spektrumu: Elemanter analiz ve Mass spektrumu ile proton miktarinın 41 tane olduğu tespit edilmiștir. Maddenin NMR spektrumu incelendiği zaman yapılan entegrasyon hesabında proton sayısının aynı olduğu ve aromatik halkaya bağlı protonların molekülde mevcut olmadığı ortaya çıkmaktadır. 


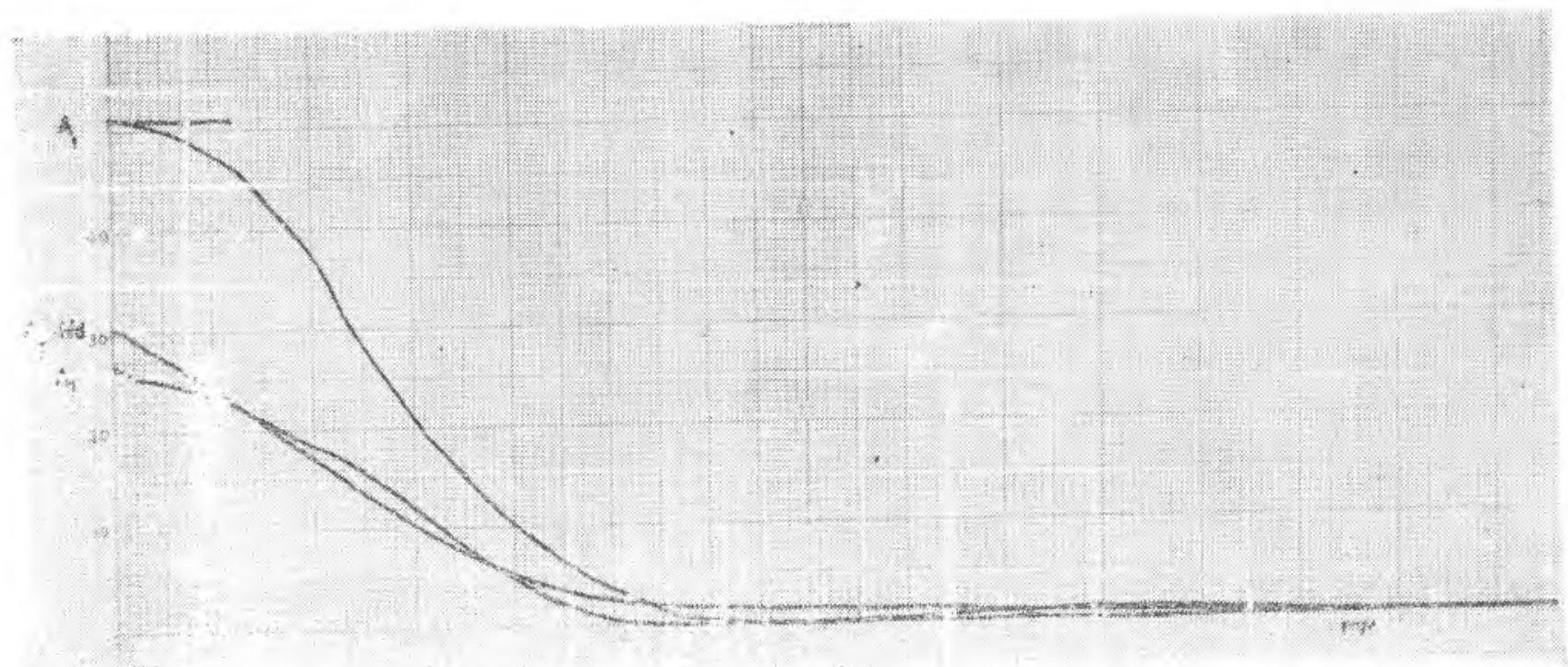

Spektr. $1-A_{1}$ Maddesi ile $A_{3}$ Maddesinin Hidroliz ürününün UV Spektrumları. 


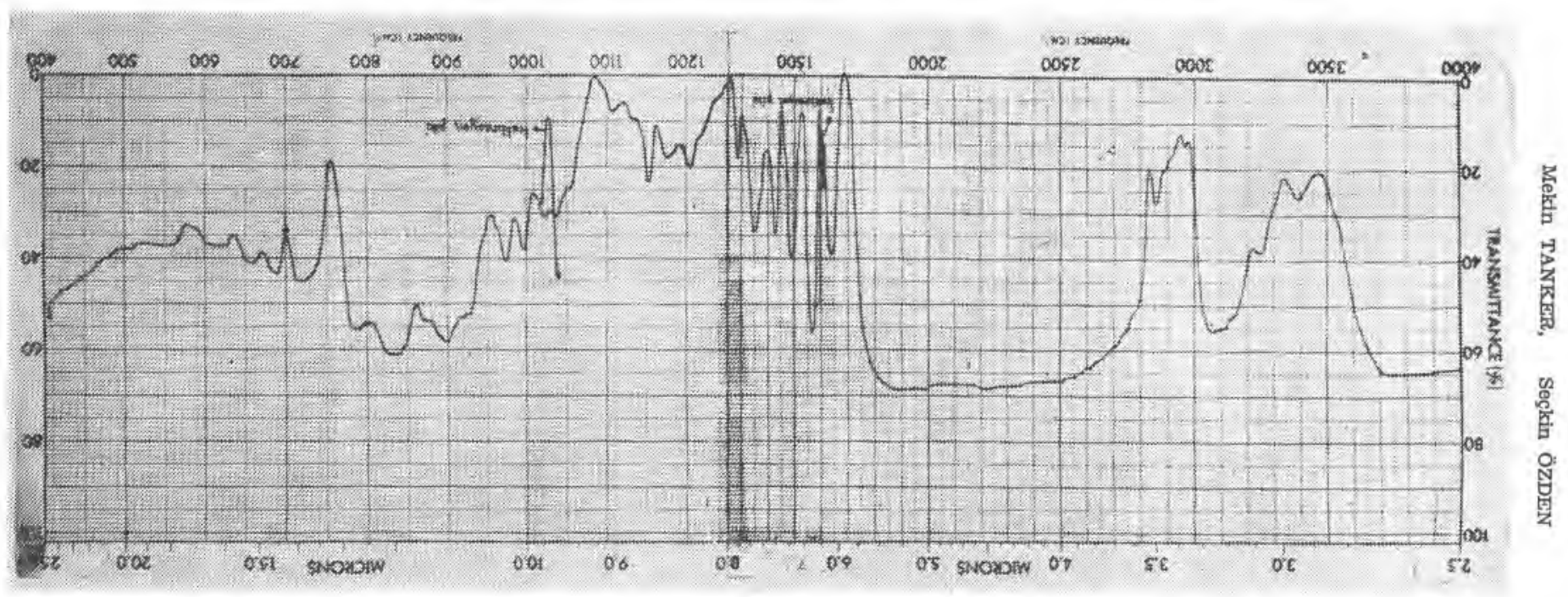

Spektr. $3-A_{1}$ Maddesinin IR Spektrumu. 


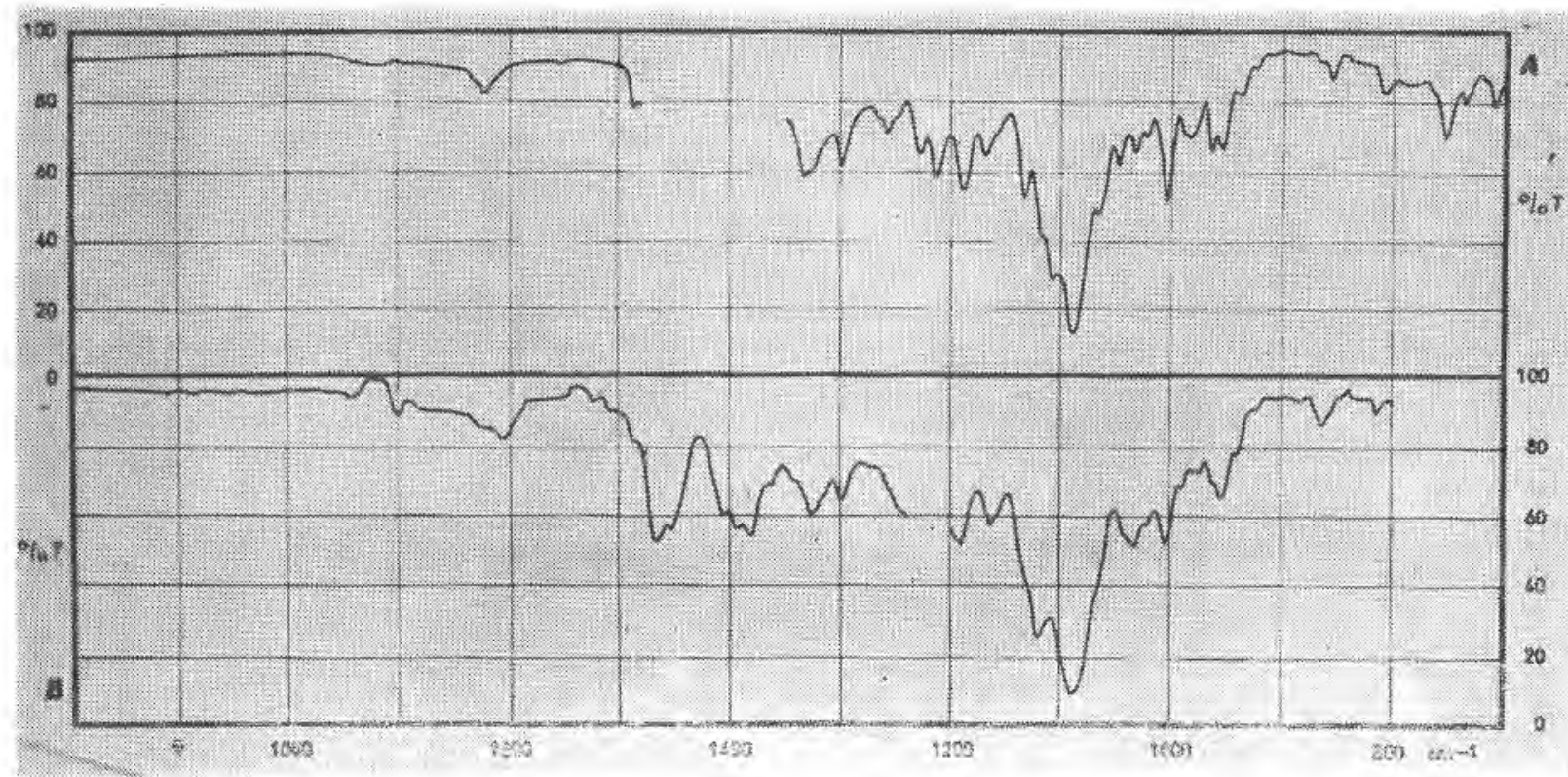

Spektr. 4 - Likoktonin'in IR Spektrumu $\left(800-1800 \mathrm{~cm}^{-1}\right)$. 

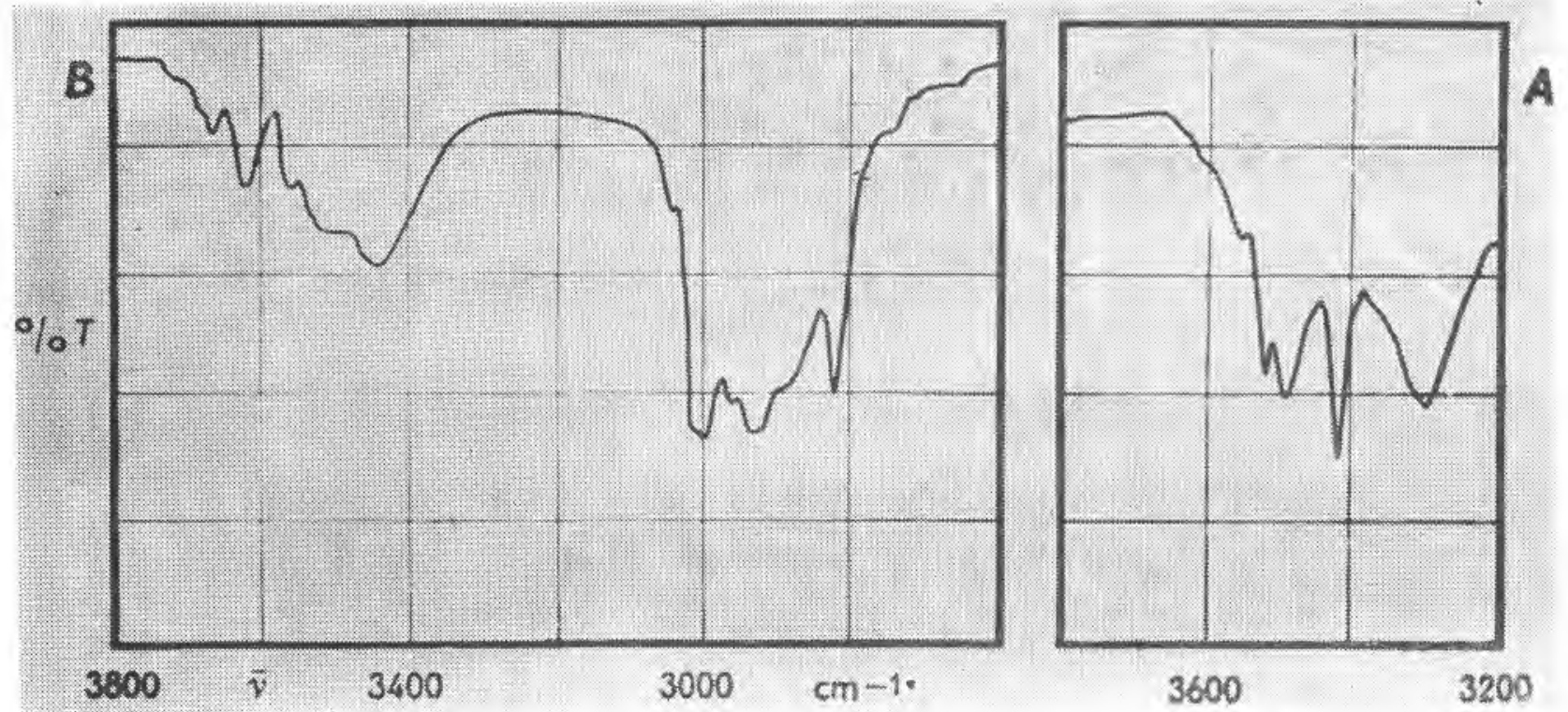

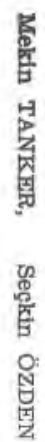

Spektr. 5 - Likoktonīn in IR Spektrumu $\left(3200-3600 \mathrm{~cm}^{-1}, 2600-3800 \mathrm{~cm}^{-1}\right)$ 


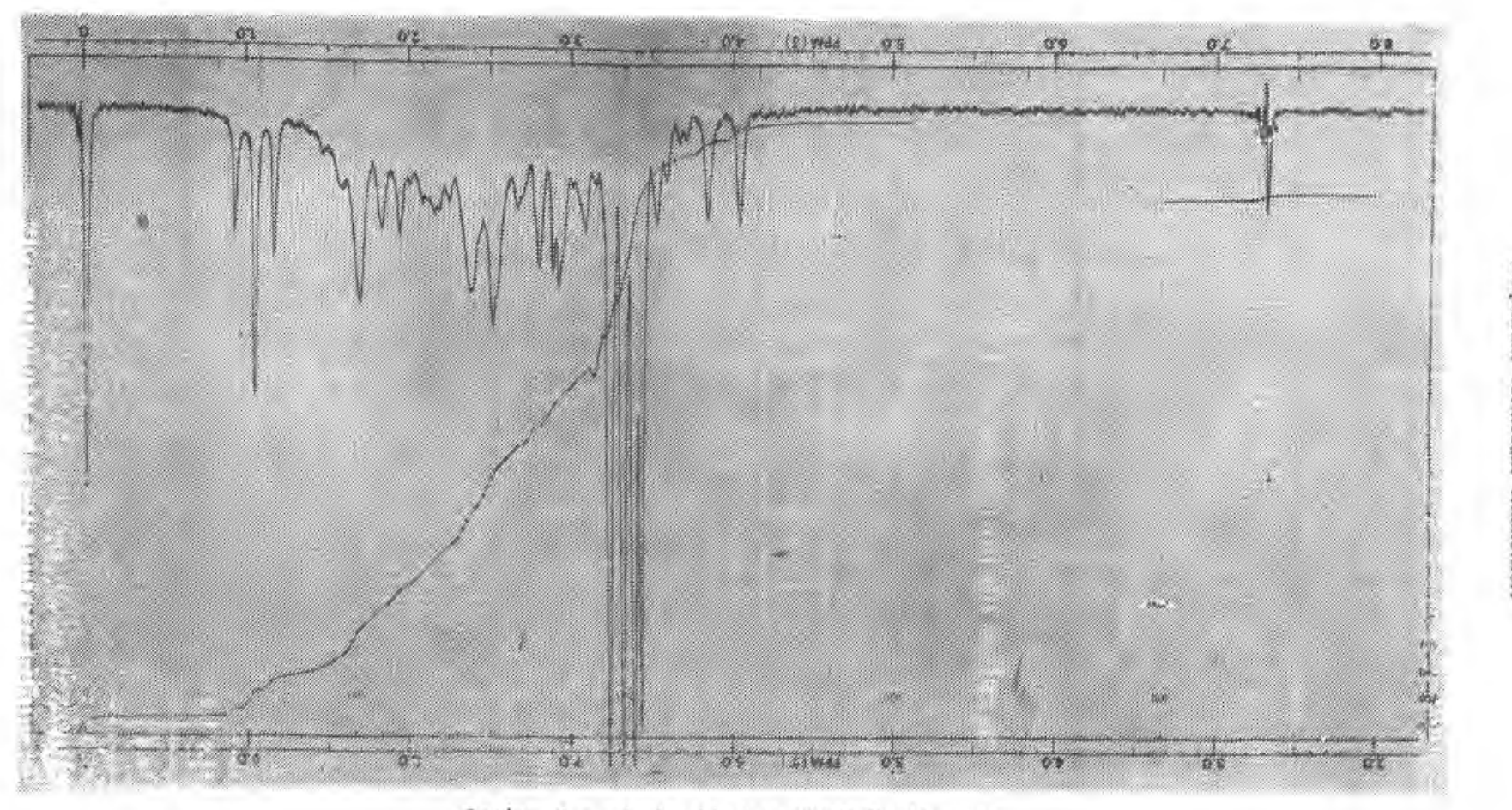

Spektr. $6-A_{1}$ Maddesinin NMR Spektrumu, 
3.2-3.5 ppm ( 8 ) arasında görülen ve her biri 6 üniteye tekabül eden 4 sinyal molekülde mevcut 4 adet metoksil grubunu göstermektedir. IR spektrumu ile ortaya çıan tersiyer azot atomuna bir etil grubunun bağlandığı $1,1 \mathrm{ppm}$ ( $\delta$ ) deki 10 üniteye tekabül eden sinyal ile görülür. 3.6-4.05 ppm $(\delta)$ arasındaki üç sinyal birer hidroksil protonlarını ișaret etmektedir. Spektrumdaki diğer sinyaller metilen grubuna bağlı poroton gruplarını vermektedir. (2.3.13.14) (Spektrum: 6).

Bütün bu neticelere göre $A_{1}$ maddesi $C_{19}$ diterpen alkaloitlerinin en önemli amino alkolü olan likoktonin ile idantiktir.

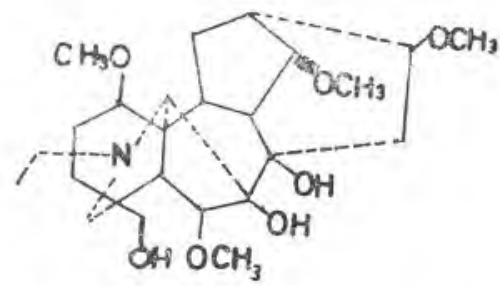

Formül 1 : Likoktonin (Lycoctonine, Royline, Delsine)

A 3 maddesi: Beyaz iğnecikler halinde kristallerdir. Dragendorff ve diğer alkaloit reaktiflerine müspet cevap vermektedir. Baz halindeki maddenin ergime noktası $125^{\circ} \mathrm{C}$ dir. Ince tabaka kromatografisinde elde edilen $\mathrm{R}_{\mathrm{f}}$ değeri, 0,44 olarak bulunmuștur. Yaptırulan elementer analiz neticesinde : C: $\% 62,67, \mathrm{H}: \%$ 7.64, N: \% 5.97, O: \% 23.72 bulunmuștur.

Mass spektrumu ile molekül tartısı 699 mol. g. olarak tespit edildi. Ayrica alkaloidin elde edilen Hidroklorik asit tuzunun $195^{\circ} \mathrm{C}$, Perklorik asit tuzunun $190^{\circ} \mathrm{C}$ de eridikleri tespit edildi. Optik çevirme derecesi $(\alpha)^{20}{ }_{D}+43$ olarak bulundu.

$A_{3}$ maddesini, alkali hidrolizi : $A_{3}$ maddesinin alkali hidrolizi ile ergime noktas $143^{\circ} \mathrm{C}$, optik çevirme derecesi $(\alpha)^{20}{ }_{\mathrm{D}}=+53 \mp 1$ olan bir alkamini verdiği tespit edilmiștir. $\mathrm{Bu}$ alkamin ince tabaka 


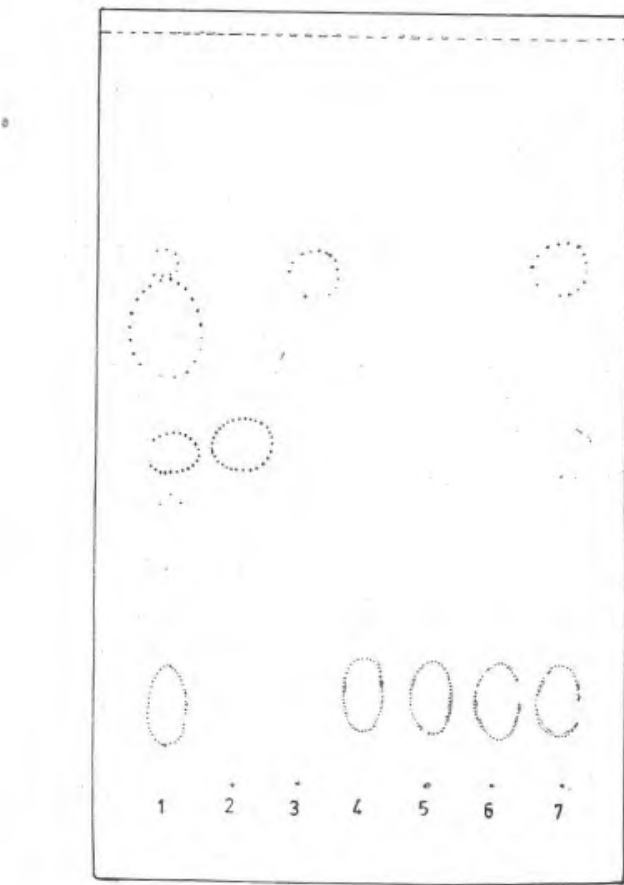

Krom. 3 - Benzen : Metanol : Eter (70:20:20)

Developman : 45 Dakika

Oda ISısı : $26^{\circ} \mathrm{C}$

1) Tüm alkaloit ekstresi.

2) $A_{3}$ alkaloidi

3) $A_{3}$ alkaloidinin asit hidroliz ürünü.

4) $A_{3}$ alkaloidinin alkali hidroliz ürünũ.

5) $A_{1}$ alkaloidi.

6) $A_{1}$ alkaloidi alkali hidroliz ürünü.

7) $A_{3}$ alkaloidi $+A_{1}$ alkaloidi $+A_{3}$ alkaloidi asit hidroliz ürünü

kromatografisinde $A_{1}$ alkaloidi ile ayni $R_{f}$ değerini vermektedir. (Kromatogram 3) Ve $A_{1}$ maddesinin diğer bütün özelliklerini gösterir. Bu alkamin IR (Spektrum: 7), NMR (Spektrum: 9) ve Mass Spektrumlarından alınan neticelerde $A_{1}$ alkaloidine tamamen uymaktadır. Ayrica bu alkaminin $A_{1}$ alkaloidi ile birbiri arkasından aynı kağıt üzerinde UV (Spektrum: i) ve IR spektrumları (Spektrum: 8) beraber alınarak her iki maddenin spektrumlarının tamamen aynı 


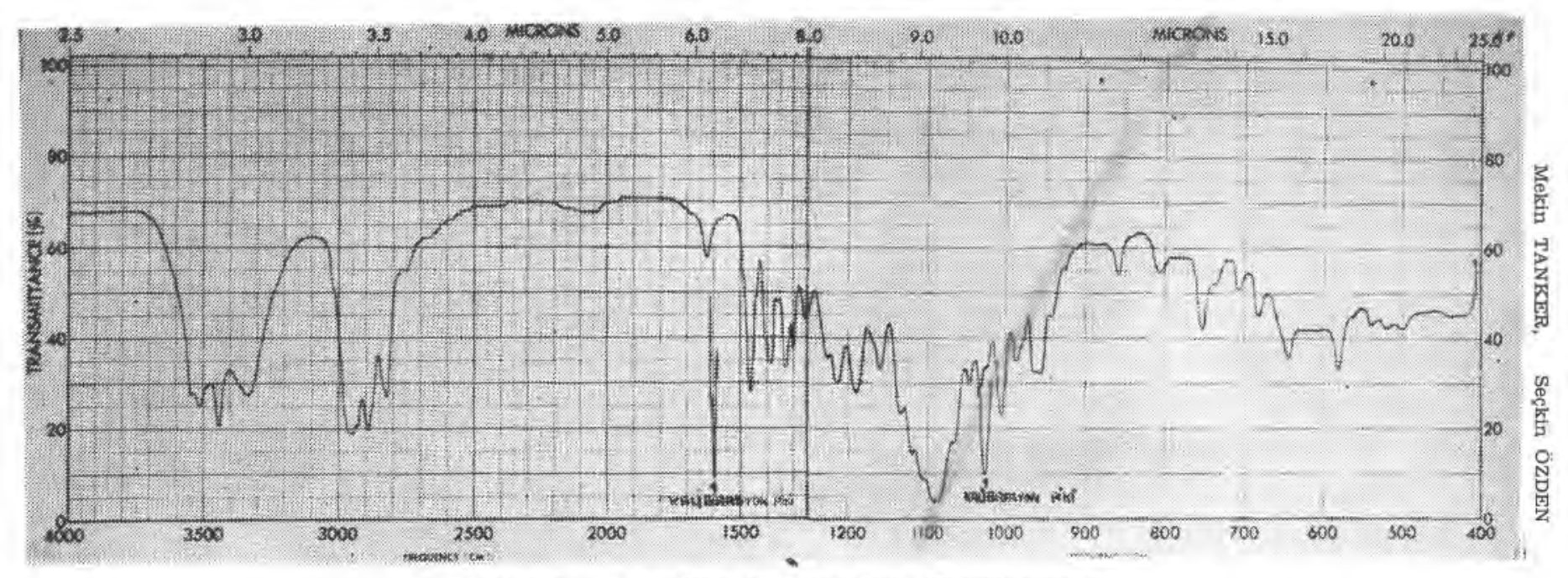

Spektr. $7-A_{3}$ maddesi hidroliz ürünün IR spektrumu. 


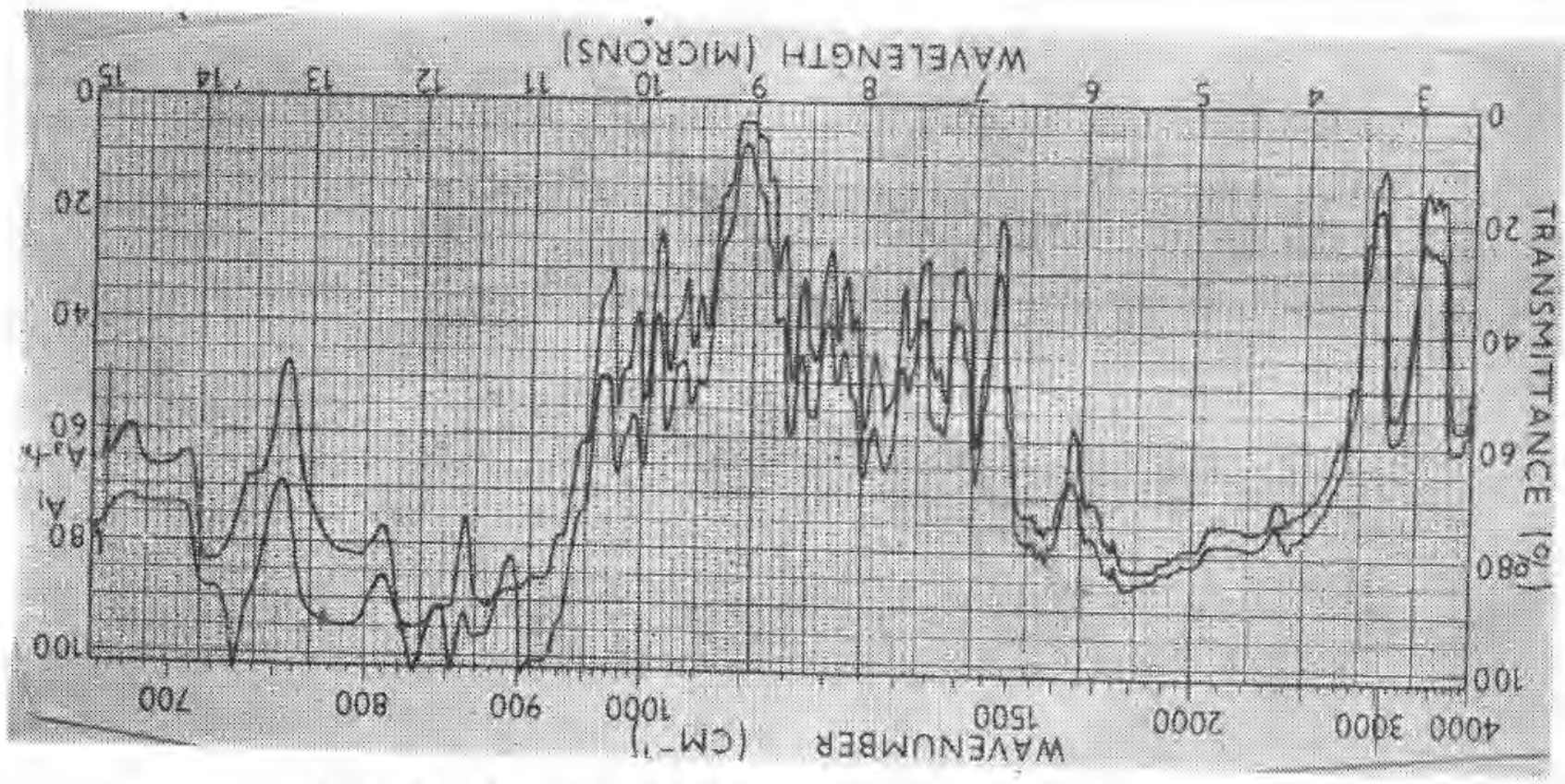

Spektr. $8-A_{3}$ maddesi hidroliz ürünü ve $A_{1}$ maddesinin If spektrumları. 


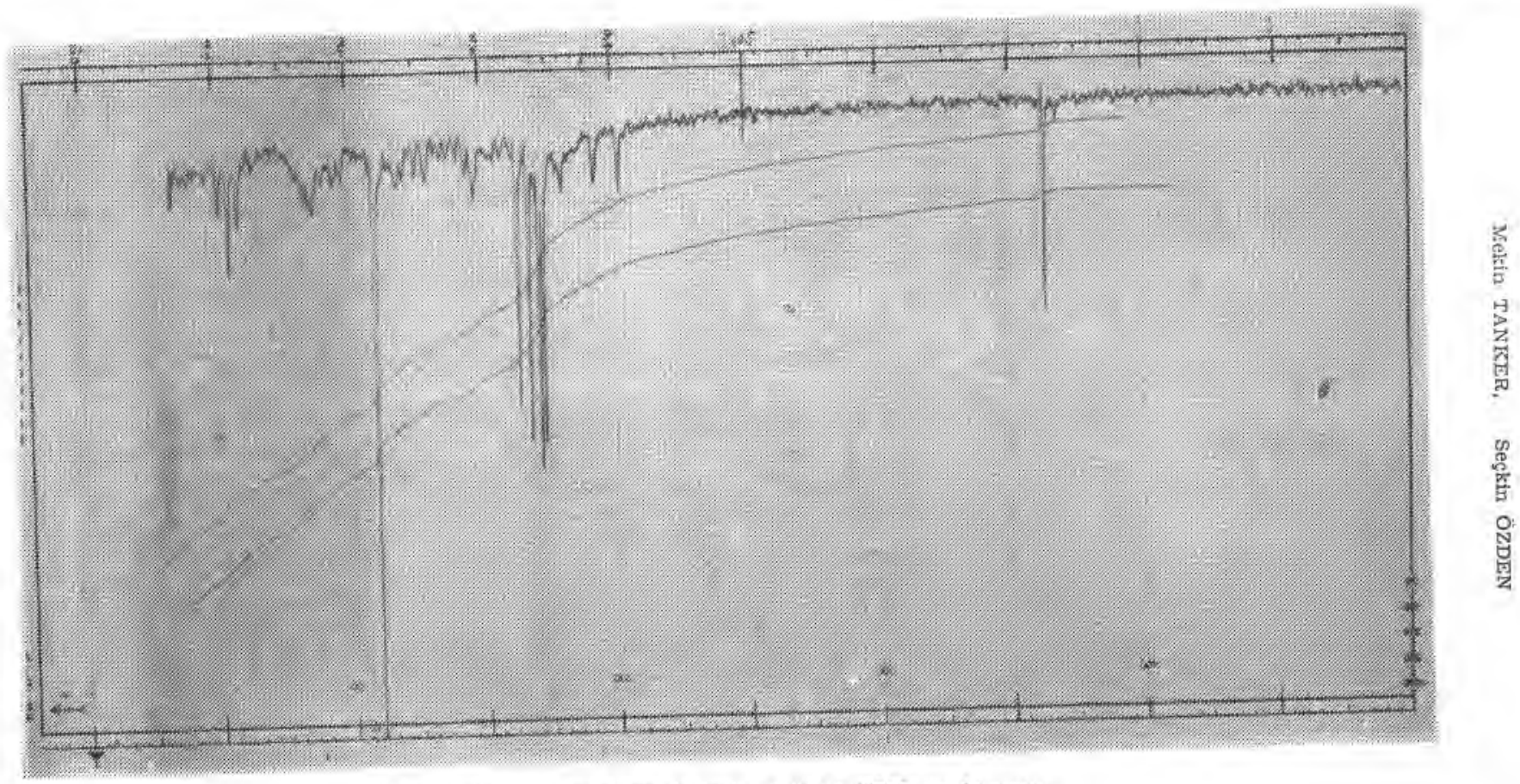

Spektr. $9-A_{3}$ maddesi hidroliz ürünün NMR spektrumu. 
olduğu daha bariz olarak görüldü. Böylece bu alkaminin $A_{1}$ maddesi ile idantik yani likotonin olduğu kati olarak anlașild.

Alkali hidroliz neticesinde elde edilen asit sarımsı kahverengi kristaller olup, ergime alanı $163-166^{\circ} \mathrm{C}$ dir. Optik çevirme derecesi $(\alpha)^{20}{ }_{D}-0,7$ dir. Bu özelliklerden $D$. semibarbatum ve $D$. oreophilum'dan $(21,22,23,24)$ izole edilen delsemin'in mono ester gurubunu teşkil eden 2 -metil süksinil- antranilik asit olabileceği düşünüldii. Bu asiti temin etme imkânı olmadığı için mukayeseli olarak çalıștamadı. Bunun üzerine bu asidi hidroliz ederek Asit I ve Asit II olmak üzere iki asit elde edildi.

$\mathrm{Bu}$ asitlerden, asit I beyaz iğnecikler halinde kristaller olup suda ve alkolde çok erir. Ergime noktası $111^{\circ} \mathrm{C}$ dir. Bu da $2-m e$ til süksinik asitin ergime noktasına uymaktadır. Şahit madde olarak temin edilen 2 -metilsüksinik asitin ergime noktası yine $111^{\circ} \mathrm{C}$ olarak bulunmuștur.

Asit II ise, sarmsı kahverengi toz halinde kristaller olup ergime noktası $145^{\circ} \mathrm{C}$ dir. Sıcak suda, alkolde, eterde çok, benzende az çözünür. Solïsyonları mavi - viyole florasans verir. Bütün bu özelliklere uyan ve șahit madde olarak temin edilen antranilik asit ile karışım ergime noktası yapıldığında yine $145^{\circ} \mathrm{C}$ olarak bulunmuștur.

$A_{3}$ maddesinin asit hidrolizi : $A_{3}$ maddesi asit hidroliz ile ergime noktası $166^{\circ} \mathrm{C}$ ve optik çevirme derecesi $(\alpha)^{25}{ }_{\mathrm{D}}+51,2$ olan bir alkaloit ve beyaz iğnecikler halinde ergime noktası $111^{\circ} \mathrm{C}$ olan bir asit vermektedir. Organik çözücülerde eriyen ve solüsyonları halinde mavi florasans gösteren bu alkaloidin bütün bu özellikleri, D. barbeyi $\mathrm{H}$, den izole edilen antranoillikoktonin'e (1) uymaktadir. Bunun üzerine bu alkaloidin alkali hidrolizi yapılarak ergime noktas $145^{\circ} \mathrm{C}$, optik çevirme derecesi $(\alpha)^{20}{ }_{\mathrm{D}}+53 \pm 1$ olan likoktonin ile sarımsı kahverengi toz halinde kristaller olan ve ergime noktası $145^{\circ} \mathrm{C}$ bulunan antranilik asit elde edilmiștir. Ince tabaka kromatografisinde antranoillikoktonin, $A_{6}$ alkaloidi ile ayn $R_{\mathrm{f}}$ degerini vermektedir.

Madde tespit edilen bu özellikleri ile delsemine idantik olabileceğini göstermektedir. Ancak $A_{1}$ de de olduğu gibi delsemin el- 
Spektr. $10-A_{3}$ maddesinin UV Spektrumui.

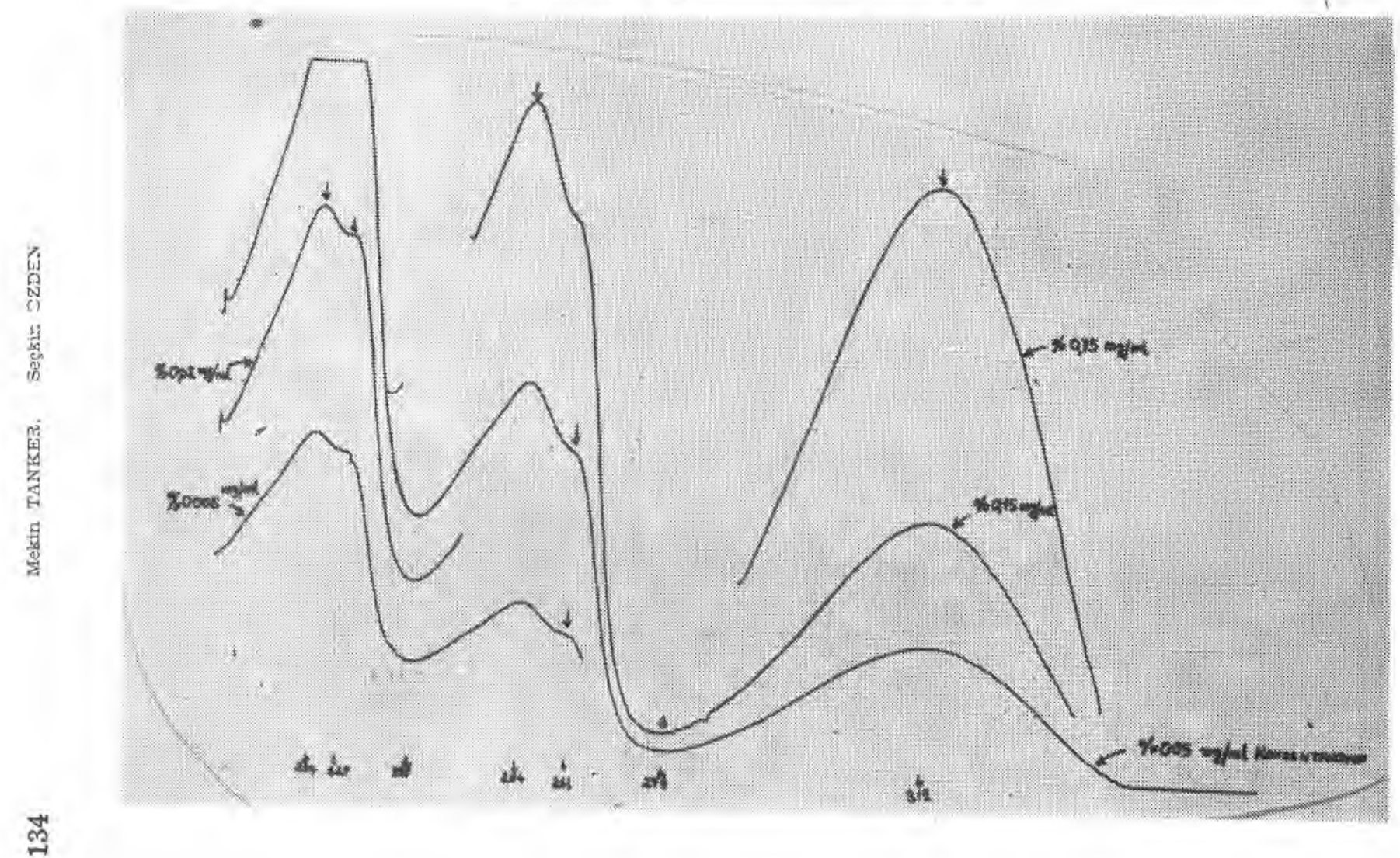




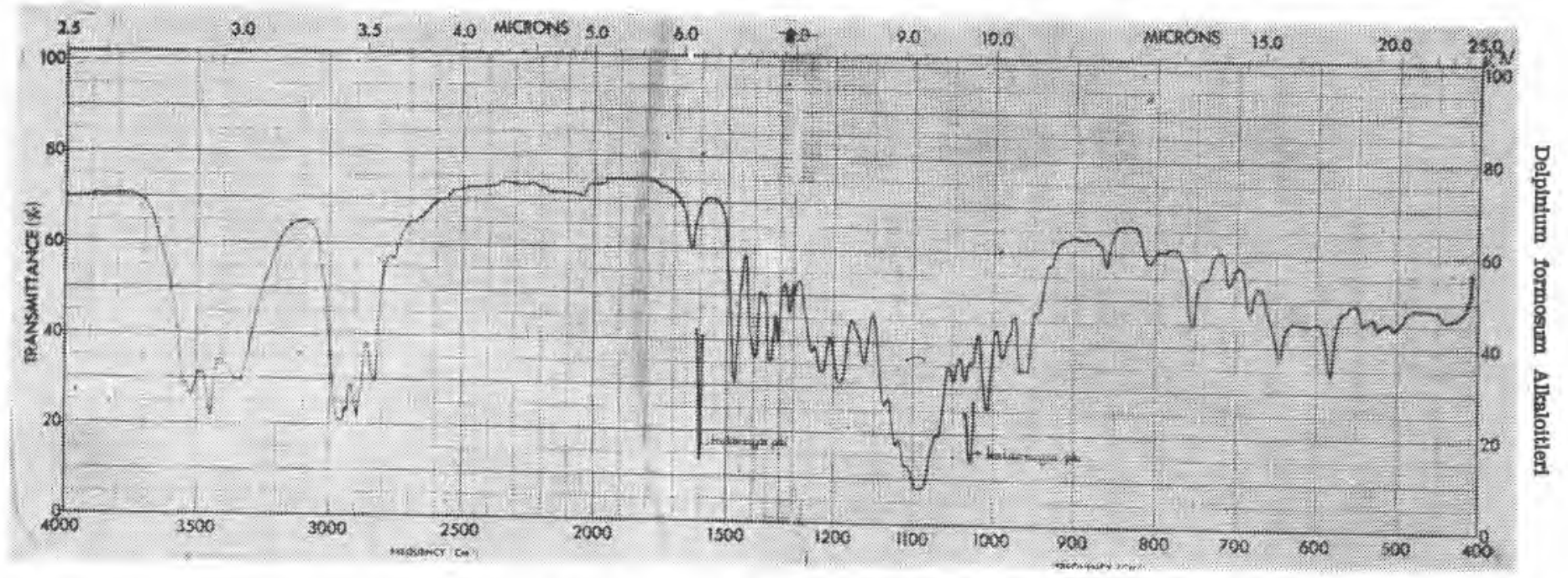

Spektr. $11-A_{3}$ maddesinin IR spektrumu 

lycoctonum L. ve Aconitum gigas Leveille et Vaniot, türlerinden elde edilen likoktonin çok zehirli olması nedeniyle tıbbî maksatlarla kullanılamıyacağı belirtildiği halde delsemin için aynı șiddetle toksisite düşünülmiyebilir. Nitekim delsemin halk arasında, bilhas. sa bitkilerle müicadelede, geniş çapta kullanılmaktadır.

\section{Ö Z E T}

Bu çalışmada $D$. formosum Boiss et Huet., bitkisinin, Trabzon'un Sürmene Santa yaylasından toplanan numuneleri üzerinde çalıșilmıștır.

$\mathrm{Bu}$ bitkinin toprak altı kısımları ince toz haline getirildikten sonra amonyak ile islatıld 1 ve benzenle perkole etmek suretiyle tüm alkaloit ekstresi elde edildi. İnce tabaka kromatografisi ile yapılan analizde tüm alkaloit ekstresinin 6 alkaloit karıșımından ibaret olduğu görüldü. Tüm ekstre üzerinde yapılan kristalizasyon çalıșmalariyla bu alkaloitlerden 2 tanesi izole edildi. Bu maddeler ergime noktaları, polarize ışığı çevirme dereceleri, asit ve alkali hidroliz leri, tuzlari ve asetile türevleri ve ayrica UV, IR, NMR ve Mass spektrumları yardımıyla teșhis ve tayin edilmișlerdir. Böylece bu maddelerin, Delphinium türlerinden daha önce izole edilen alkaloitlerden likoktonin $\left(A_{1}\right)$ ve delsemin $\left(A_{3}\right)$ ile aynı olduğu açıklanmıştır.

$\mathrm{Ph}$. Internationalis'in Aconitum alkaloitleri için vermiş olduğu metot ile yapılan miktar tayininde netice delfinin üzerinden hesaplanacak olursa \% 2.08, delsemin üzerinden hesaplanırsa $\% 2.42$ olarak bulunmuştur.

Gravimetrik yolla yapılan tüm alkaloit miktar tayininde ise bulunan netice \% 2.7 dir.

Bir seri fare üzerinde yapilan denemeler neticesinde $\mathrm{LD}_{50} 37.4$ $\mathrm{mg} / \mathrm{kg}$ olarak tespit edilmiştir. (delsemin için).

\section{RE S U M E}

Ce travail présente une étude de Delphinium formosum Boiss et Huet. L'échantillon utilisé est originaire de la région de Sürmene (Trabzon) et a été recoltée sur le plateau de Santa. On a réalisé une mouture des racines de plante, puis la poudre obtenue a été humec- 
adet metilenik karakterdeki protonları vermektedir. Molekülde 12 protona tekâbül eden 4 metoksil grubunun varlığının 3.28-3.45 ppm $(\sigma)$ arasında elde edilen 4 sinyal ispatlamaktadır.

Bütün bu bulgulara göre $A_{3}$ maddesinin $D$. semibarbatum Bien ve $D$. oreophilum $H$. dan izole edilen delsemin ile aynı olduğu anlașilmıştır.

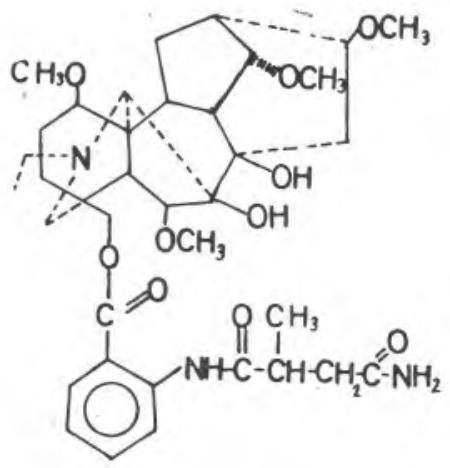

Formül : 2 Delsemin

\section{Toksisitesi}

Delphinium türleri memlektimizin belli bașlı zehirli bitkilerinden biri olması bakımından önemlidir. D. formosum Boiss et Huet; un hayvancılığımızın yaygın olduğu bir bölgede yetişmesi nedeniyle, bu bölgede hayvanlar arasında rastlanan zehirlenme olaylarında ne dereceye kadar etken olduğu hakkında bir fikir edinebilmek ve diğer Delphinium türlerinden elde edilen alkaloitlerle bu konuda mukayese etmek gayesi ile letal dozu tespit edilmiștir. Bunun için $\mathrm{A}_{3}$ alkaloitinin hidroklorik asit tuzunun, serum fizyolojik içinde hazırlanmış solüsyonu intraperitonal olarak, ortala- 
ma ağırlıkları 13,3 g olan 30 fareye verildi, buna göre çizilen doz ölüm eğrisinden $I D_{50} 37,4 \mathrm{mg} / \mathrm{kg}$ olarak tespit edildi.

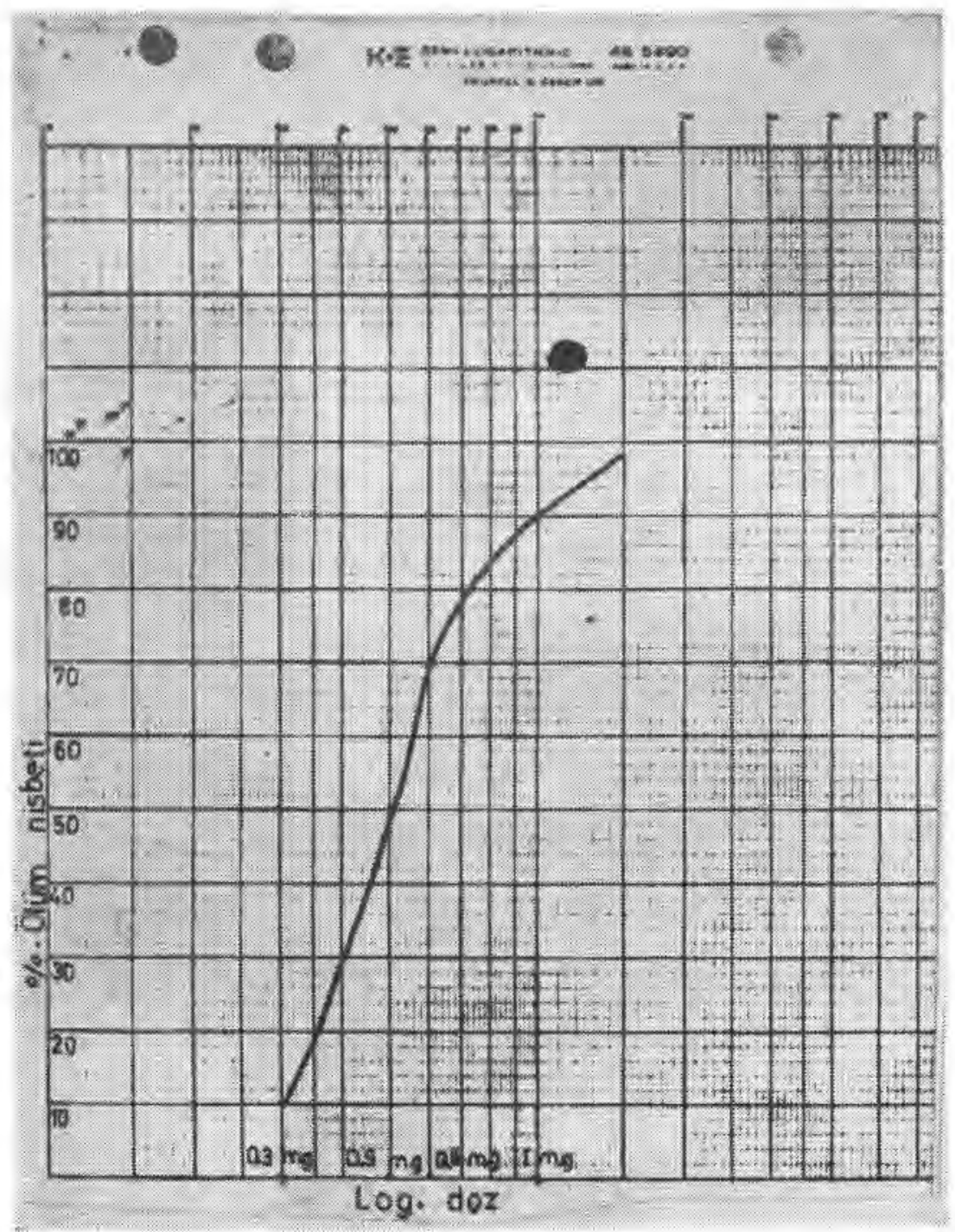

Delsemin in doz ölüm eğrisi 